\title{
Improved cement mortars by addition of carbonated fly ash from solid waste incinerators
}

\author{
O. López-Zaldívar ${ }^{\mathrm{a}} \bowtie$ P.L. Mayor-Lobo ${ }^{\mathrm{a}}$, F. Fernández-Martínez ${ }^{\mathrm{b}}$, F. Hernández-Olivares ${ }^{\mathrm{c}}$ \\ a. School of Building. Technical University of Madrid (UPM) (Madrid, Spain) \\ b. School of Industrial Design and Engineering. Technical University of Madrid (UPM) (Madrid, Spain) \\ c. School of Architecture. Technical University of Madrid (UPM) (Madrid, Spain) \\ \oscar.lopezz@upm.es
}

\author{
Received 13 October 2014 \\ Accepted 27 February 2015 \\ Available on line 22 July 2015
}

\begin{abstract}
This article presents the results of a research developing high performance cement mortars with the addition of municipal solid waste incineration fly ash (MSWIFA) stabilized as insoluble carbonates. The encapsulation of hazardous wastes in mortar matrixes has also been achieved. The ashes present high concentrations of chlorides, $\mathrm{Zn}$ and $\mathrm{Pb}$. A stabilization process with $\mathrm{NaHCO}_{3}$ has been developed reducing $99 \%$ the content of chlorides. Developed mortars replace 10\% per weight of the aggregates by treated MSWIFA. Physical/mechanical properties of these mortars have been studied. Presence of $\mathrm{Zn}, \mathrm{Pb}, \mathrm{Cu}$ and $\mathrm{Cd}$ has been also analyzed confirming that leaching of these heavy metal ions is mitigated. Conclusions prove better behavior of CAC and CSA mortars than those of CEM-I and CEM-II cement. Results are remarkable for the CAC mortars, improving reference strengths in more than $25 \%$, which make them a fast-curing product suitable for the repair of structures or industrial pavements.
\end{abstract}

KEYWORDS: Mortar; Fly ash; Calcium carbonate; Aggregate; Calcium aluminate cement.

Citation/Citar como: López-Zaldívar, O.; Mayor-Lobo, P.L.; Fernández-Martínez, F.; Hernández-Olivares, F. (2015) Improved cement mortars by addition of carbonated fly ash from solid waste incinerators. Mater. Construcc. 65 [319], e062. http://dx.doi.org/10.3989/mc.2015.07114.

RESUMEN: Morteros de cemento mejorados con la adición de cenizas volantes carbonatadas provenientes de la incineración de residuos. Este artículo presenta los resultados del desarrollo de morteros mejorados con la incorporación de cenizas volantes de residuos sólidos urbanos inertizadas en forma de carbonatos. Además se consigue la encapsulación de un residuo peligroso. Las cenizas presentan una alta concentración de cloruros, $\mathrm{Zn}$ y $\mathrm{Pb}$. Se ha desarrollado un proceso de estabilización con $\mathrm{NaHCO}_{3}$ reduciendo en un $99 \%$ el contenido de cloruros. Los morteros reemplazan un $10 \%$ en peso del árido por cenizas tratadas. Se han analizado sus propiedades físico/mecánicas y la presencia de $\mathrm{Zn}, \mathrm{Pb}, \mathrm{Cu}$ y $\mathrm{Cd}$. Se demuestra un mejor comportamiento de los morteros de CAC y CSA que los de CEM-I y CEM-II y se mitiga el lixiviado de metales pesados. Los resultados son significativos en los morteros CAC al mejorar las resistencias de los de referencia en un $25 \%$. Los morteros desarrollados son de curado rápido adecuados para la reparación de estructuras o soleras industriales.

PALABRAS CLAVE: Mortero; Ceniza volantes; Carbonato cálcico; Árido; Cementos de aluminato de calcio.

Copyright: (C) 2015 CSIC. This is an open-access article distributed under the terms of the Creative Commons Attribution-Non Commercial (by-nc) Spain 3.0 License. 


\section{INTRODUCTION AND OBJECTIVES}

Urban development promotes the increase of municipal solid waste incineration (MSWI), with the consequent problem of collection, transportation and storage. Currently, incineration is presented as the best possible method to manage this waste (1-3). But the incineration of MSW produces fly ashes with high heavy metal content that must be handled, with the added difficulty of their consideration in the European list of hazardous waste (4).

The present legislation ${ }^{1}$ and the future environmental legislation ${ }^{2}$, together the technological developments carried out in the past years, predict an improvement in the management of MSW processing plants, minimizing pollutant emissions to reduce their environmental impact. Recent researches have analyzed the implementation of these improvements restricted to collecting and processing organic waste and wastewater $(5,6)$. In Battistoni, P., et al., 2007 (7), the aim is to integrate the municipal management of MSW within small towns and decentralized areas. This integrated performance over all the MSW produces savings both in transport, and in their management, as well as an optimization of the consumption of generated energy, and a few new low cost by-products.

At the same time, new techniques of urban solid waste treatment are established as a transformative

\footnotetext{
The Royal Decree 653/2003 on waste incineration, the Directive 2000/76/CE and the Directive 2006/12/CE from the European Parliament and the European Council of April 5th, 2006 on waste are the main norms forming the legislative body regulating the incinerating plants. According to them, the State Members of the EU should promote the adequate measures to encourage:

- Prevention and/or reduction of waste generation and their hazard.

- Waste valorization by recycling or recuperation processes, giving them a new use, or any other action in order to obtain secondary raw materials.

- The use of waste as energy source.
}

The Directive "Waste acceptance criteria in landfill" (1999/31/EC; 2003/33/EC) also defines the different categories of waste (municipal waste, hazardous waste, non-hazardous waste and inert waste) and applies to all landfills, defined as waste disposal sites for the deposit of waste onto or into land.

${ }^{2}$ In 2014 new prevention aims have been established at a European level, which will be mandatory in 2020, regarding heavy metals components in ashes, as stable salts. Ashes containing them should be placed in special packing, or should be vitrified by plasma technology. element of the urban landscape, involving architects and urban planners in the modification of the social organization. Similarly, a new way of relating the inhabitants of urban contexts and this new environment is fostered, like they do with the general network of sanitation or water or electricity supply. In this way, the day itself is the generator of resources or byproducts, achieving the commitment that each district or new created settlement is self-sufficient and that they use up their own self-generated resources.

The implementation of waste shredding systems in urban settings of new creation, besides or in combination with the selective waste collection processes, favors direct collection, channeling it to processing plants of smaller size than the current ones, with better social and aesthetic implementation in the urban landscape. Once there, waste would be classified, purified, dried, and prepared for incineration.

In the process of incineration of urban solid waste, $75 \%$ of the generated products are estimated to be combustion gases, while the remaining $25 \%$ is the solid remnant of it. Of this amount, $21 \%$ are slags and bottom ashes, while the remaining $4 \%$ corresponds to fly ash $(8,9)$. MSWI fly ashes represent a very serious environmental problem. During the incineration process, the finest ash fraction is mixed with the combustion gases giving rise to a granular product containing large quantities of easily leachable heavy metals, as well as other toxic substances (dioxins, furans, PAHs, etc.). Fly ashes must be treated, stabilized or encapsulated with the objective of reducing its environmental impact, in order to be subsequently valorized and used as a construction material (10-15).

The first objective of the present research aims to transform the waste formed mainly by calcium hydroxide and calcium hydroxychlorides into another limy-type material -calcium carbonate material. This is achieved by transforming the high soluble heavy metals chlorides into low soluble carbonates.

The second objective focuses on the stabilization and use of this MSWI fly ash as part of the aggregates used in the production of cement mortars (16-19) demonstrate that the mortars elaborated with ordinary Portland cement represent a very safe way of reusing these hazardous materials and play an important part in the encapsulation of heavy metals. However, those studies emphasize that the mechanical strength of mortars resulting from the incorporation of fly ash as a partial substitute for the aggregate were significantly affected when compared to the reference mortars.

In addition, the use of calcium aluminate cement (CAC) has been demonstrated to be a highly effective way to safely encapsulate hazardous materials $(20,21)$ as well as the use of sulfoaluminate cements (CSA) (22). In addition, carbonation process in CAC cements and pastes are reported to increase 
mechanical strength (23). On the basis of the foregoing, it was decided to perform a screening and statistical analysis comparing mortars manufactured with ordinary Portland cements (CEM-I and CEM-II) and fast-setting cements (CAC and CSA). Calcium sulfoaluminate cements (CSA) were also chosen due to the perception that sulphur content would make the precipitation of heavy metals in the form of sulphides easier.

\section{EXPERIMENTAL WORK}

\subsection{Materials}

\subsubsection{Cement}

To produce the mortars, four types of different cements were used:

- Two ordinary Portland cements, Type I 52,5 R (CEM-I) and Type II A/P 42,5 R (CEM-II), both from CEMEX ESPANA S.A.B, from the plant in Castillejo, Toledo (Spain).

- Calcium Aluminate Cement (CAC) from Cementos Molins Industrial, S.A. Company, named commercially as Electroland. It is a $100 \%$ grinded clinker without additions, coming from Sant Vicenç dels Horts plant, in Barcelona (Spain).

- Finally, Calcium Sulfoaluminate Cement (CSA) named ALIPRE has been used. It is grinded sulfoaluminate-belite clinker composed by: Calcium, Sulfoaluminate, Belite and Calcium Sulfate. It comes from the Arrigorriaga plant Bilbao (Spain) of the Italcementi Group.

\subsubsection{Aggregate}

The criteria for the selection of the aggregates was based on the intention of performing statistical analysis on how these fine particles of fly ash could affect the hydration of mortars, since water retention capacity is directly related to the specific surface of the aggregate. To this end, the aggregate chosen was washed silica sand, ranging between $0 / 2$ and $0 / 4 \mathrm{~mm}$ in diameter, from the gravel pit of Sotopajares, San Martín de la Vega, Madrid (Spain). Both diameters comply with UNE-EN 13043:2003/AC: 2004 standard on mortars.

\subsubsection{Fly ash}

MSWI fly ash came from the integral waste treatment plant of Mataró, Barcelona (Spain), which performs the process of incineration in a moving grate. Approximately $100 \mathrm{~kg}$ of fly ash were collected in ESP/baghouse during the month of January 2010 and stored in barrels sealed for later use and study in the laboratory.

\subsection{Experimental procedure}

\subsubsection{Chemical composition of MSWI fly ash}

Clear solution of nitric acid digeste original fly ash (FA) and treated fly ash (TFA) were analyzed, on the basis of a macro elemental study by Optical Emission Spectrophotometry techniques with Inductive Coupling Plasma SPECTRO (model ICP-OES ARCOS), and elementary components, through Mass Spectrometry with Inductive Coupling Plasma VARIAN ICP-MS (model ULTRAMASS). Ionic Chromatography with conductometric detector (DIONEX-DX500 model) was also used in such analysis.

Finally, with the aim of checking the total carbonation process, FA and TFA ashes were also evaluated by using SDT-Q600 Thermo Gravimetric Analyzer and simultaneously Differential Scanning Calorimeter (TGA-DSC), in order to show the transitions related to the decomposition of both ashes showing details about the chemical reactions. This analysis provides simultaneous measurement of weight and true differential heat flow on the mortar samples from ambient temperature to $1000^{\circ} \mathrm{C}$. Smashed mortar samples are placed on $110 \mu$ l platinum pans and compared to empty reference pans. Both are placed into the furnace at a heating rate of $20{ }^{\circ} \mathrm{C} / \mathrm{min}$. At the same time, a nitrogen gas system with mass flow control provides better baselines and removes decomposition products from the samples for a precise metering. At this rate and atmosphere, TGA signals record the different dehydration steps of the samples and DSC trace shows the loss of water plus higher temperature solid state phase and melting transitions respectively.

\subsubsection{Fly ash stabilization process}

2.2.2.1. Search of possible reagents to be used in the stabilization process A search of the possible reagents has been carried out to use them in the stabilization process of fly ash, taking into account its heavy metal content. To this end, literature has been reviewed finding various anions that would react with the present soluble heavy metals and, that would generate an insoluble precipitate (24). The most important data to take into account is the $25^{\circ} \mathrm{C}$ solubility product, defined by the neutral water equilibrium constant for the reaction of the compound dissolution $\left(\mathrm{B}_{\mathrm{y}} \mathrm{C}_{\mathrm{x}}\right)[1]$ :

$$
\mathrm{B}_{\mathrm{y}} \mathrm{C}_{\mathrm{x}(\mathrm{s})} \rightleftarrows \mathrm{yB}^{\mathrm{x}-}{ }_{(\text {aq. })}+\mathrm{xC}^{\mathrm{y}+}{ }_{\text {(aq.) }}
$$

In this way, considering previous researches $(25,26)$ aiming to stabilize heavy metals and, at the same time to eliminate part of chlorides of fly ash through washing, an alternative method using 
$\mathrm{NaHCO}_{3}$ is established. An appropriate combination of this will exercise a buffer function and maintain $\mathrm{pH}$ at an optimum value, for which the heavy metals content in the leachate will be minimal. Likewise, the addition of $\mathrm{Na}^{+}$ion in equivalent quantities to chloride ions, in the fly ash washing process, will facilitate the removal of a large amount of chlorides in the form of sodium chloride. In addition, $\mathrm{NaHCO}_{3}$ is a cheap and safe stabilizing agent and does not alter the $\mathrm{pH}$ of cementitious materials.

2.2.2.2. Determining $\mathrm{NaHCO}_{3}$ quantity to be used in the stabilization reaction. In order to eliminate most of the chloride from the fly ash, the equivalent number of it will be taken as reference to determine the equivalent sodium required and to complete the elimination of chloride. At the same time, the $\mathrm{CO}_{3}^{2-}$ anion carbonate reacts with the existing heavy metals ions to form insoluble carbonates.

In order to quantify the chloride content, a weighed ash amount is completely dissolved in diluted nitric acid and subsequently the free chloride ion is quantified by potentiometric silver titration. The number of gram-equivalent obtained per mass unit will also be the number of gram-equivalents of $\mathrm{NaHCO}_{3}$ used per mass unit (127 $\mathrm{mg}$ of $\mathrm{Cl}^{-} / \mathrm{gr}$ of fly ash sample or $3.24 \mathrm{Eq} / \mathrm{Kg} \mathrm{de} \mathrm{Cl}^{-}$).

\subsubsection{Stabilization process and valorization of} MSWI fly ash. The stabilizing procedure began by washing the original ashes, with a proportion of deionized water/fly ash of 10: 1 . To that effect, 4 $\mathrm{kg}$ of fly ashes were placed in $40 \mathrm{dm}^{3}$ of water and this mixture was manually stirred by mechanical means during 15 minutes, while the same equivalents amount of $\mathrm{NaHCO}_{3}$ was added to the initially present chloride. The resulting $\mathrm{pH}$ obtained results of 8.3, which ensures that heavy metals are precipitated in form of carbonate or hydroxides and not redissolved, while plumbite or zincate anions are not generated as will be occurring at a higher $\mathrm{pH}$ level. Indeed, in alkaline medium solubility of heavy metal carbonates or hydroxides is lower than the calculated from the solubility constant for metal carbonates or metal hydroxides in neutral water (24).

The mixture was left to rest for 24 hours. The liquid part, composed mostly of sodium chloride $(\mathrm{NaCl})$ dissolved in water, was removed and analyzed by ICP-OES (Table 1). Chloride analyses were made by Ionic Chromatography. The heavy metals low levels obtained as analytical results of the first washing lixiviate are shown in Table 1. In accordance to the value limits established in the European Directive for acceptable waste at landfills $(27,28)$, the washing water could be handled as a non-hazardous waste. In order to reduce the high chloride content in TFA, a total of three deionized water washings were performed, after which the TFA recovery process was started by filtering at low
TABLE 1. Analytical ICP-OES and Ion Chromatography findings of the water taken from the first washing

\begin{tabular}{|c|c|}
\hline Parameter & Sample Na 1.72 and Cl $2.6 \mathrm{~g} / \mathrm{L}$ \\
\hline $\mathrm{Al}\left(\mu \mathrm{g} \mathrm{ml}^{-1}\right)$ & $0.11 \pm 0.02$ \\
\hline $\operatorname{As}\left(\mu \mathrm{g} \mathrm{ml}^{-1}\right)$ & $<0.020$ \\
\hline $\mathrm{Ba}\left(\mu \mathrm{g} \mathrm{ml} \mathrm{l}^{-1}\right)$ & $0.098 \pm 0.010$ \\
\hline $\mathrm{Ca}\left(\mu \mathrm{g} \mathrm{ml}^{-1}\right)$ & $105 \pm 5$ \\
\hline $\mathrm{Cd}\left(\mu \mathrm{g} \mathrm{ml}^{-1}\right)$ & $<0.020$ \\
\hline Co $\left(\mu \mathrm{g} \mathrm{ml}^{-1}\right)$ & $<0.020$ \\
\hline $\mathrm{Cr}\left(\mu \mathrm{g} \mathrm{ml} \mathbf{l}^{-1}\right)$ & $0.24 \pm 0.08$ \\
\hline $\mathrm{Cu}\left(\mu \mathrm{g} \mathrm{ml}^{-1}\right)$ & $<0.020$ \\
\hline $\mathrm{Fe}\left(\mu \mathrm{g} \mathrm{ml}^{-1}\right)$ & $<0.020$ \\
\hline $\mathbf{K}\left(\mu \mathrm{g} \mathrm{ml}^{-1}\right)$ & $620 \pm 60$ \\
\hline $\operatorname{Mg}\left(\mu \mathrm{g} \mathrm{ml}^{-1}\right)$ & $<0.020$ \\
\hline $\operatorname{Mn}\left(\mu \mathrm{g} \mathrm{ml}^{-1}\right)$ & $<0.010$ \\
\hline $\mathrm{Ni}\left(\mu \mathrm{g} \mathrm{ml}^{-1}\right)$ & $<0.020$ \\
\hline $\mathbf{P}\left(\mu \mathrm{g} \mathrm{ml}^{-1}\right)$ & $<0.020$ \\
\hline $\mathrm{Pb}\left(\mu \mathrm{g} \mathrm{ml} \mathrm{l}^{-1}\right)$ & $0.31 \pm 0.03$ \\
\hline $\mathrm{S}\left(\mu \mathrm{g} \mathrm{ml}^{-1}\right)$ & $141 \pm 6$ \\
\hline $\mathrm{Sb}\left(\mu \mathrm{g} \mathrm{ml}^{-1}\right)$ & $<0.020$ \\
\hline $\mathrm{Si}\left(\mu \mathrm{g} \mathrm{ml}^{-1}\right)$ & $1.3 \pm 0.1$ \\
\hline $\operatorname{Sn}\left(\mu \mathrm{g} \mathrm{ml}^{-1}\right)$ & $<0.050$ \\
\hline $\operatorname{Sr}\left(\mu \mathrm{g} \mathrm{ml}^{-1}\right)$ & $0.15 \pm 0.02$ \\
\hline $\mathrm{Ti}\left(\mu \mathrm{g} \mathrm{ml}^{-1}\right)$ & $10,4 \pm 0,5$ \\
\hline $\mathrm{W}\left(\mu \mathrm{g} \mathrm{ml}^{-1}\right)$ & $<0.010$ \\
\hline $\mathrm{Zn}\left(\mu \mathrm{g} \mathrm{ml} \mathbf{l}^{-1}\right)$ & $0.16 \pm 0.03$ \\
\hline $\mathrm{Zr}\left(\mu \mathrm{g} \mathrm{ml}^{-1}\right)$ & $<0.020$ \\
\hline $\mathrm{Cl}^{-}\left(\mu \mathrm{g} \mathrm{ml}^{-1}\right)$ & $2540 \pm 127$ \\
\hline
\end{tabular}

pressure and washing through a Büchner funnel of $2 \mathrm{dm}^{3}$ capacity connected to a Kitasato flask and a vacuum pump.

The recovered paste was placed on trays to dry in a furnace for 24 hours, at $75^{\circ} \mathrm{C}$ temperature. A dry cake of brittle material was obtained which was then manually grinded and sifted through a sieve of $63 \mu \mathrm{m}$. The greyish powder obtained, mostly calcite and portlandite phases, is easily combinable with the selected aggregates for the mortars implementation.

\subsubsection{Fresh mortar}

In order to develop high performance cement mortars by the addition of municipal solid waste incineration fly ash stabilized in the form of insoluble carbonates, two different types of standardized mortar specimens of the four referred cements were carried out: a first reference mortar (R) without additions, and a second MSWI fly ash mixed mortar replacing $10 \%$ in weight of the aggregates by treated fly ash (TFA) in accordance with research literature (29-32). 
Likewise, all mortar samples cover different cement proportions both using aggregates with different diameters $(0 / 2$ and $0 / 4 \mathrm{~mm}$ range) and different cement/aggregate ratios (1/1 and 1/3).

The consistency of all samples was carried to a runoff value of $175 \pm 10 \mathrm{~mm}$ determined by the flow table in accordance with EN 1015-3: 2000 standard concerning mortars with bulk densities higher than $1200 \mathrm{~kg} / \mathrm{m}^{3}$.

In samples of fresh mortar, in turn, the workability period in minutes was determined, as defined in the EN 1015-9: 2000 European standard on current use masonry mortars.

\subsubsection{Hardened mortar}

Mortar specimens of $4 \times 4 \times 16 \mathrm{~cm}^{3}$ were prepared in steel molds, unmolded at 24 hours and cured at $20{ }^{\circ} \mathrm{C}$ immersed in water, complying with the test method stated in EN 196-1 European standard.

Since the final result is a construction product, it has become necessary to evaluate dimensional and volumetric stability of the different mortars in order to avoid mixtures with shrinkage or expansion movements which may provoke cracks or fractures in the material. Based on this, a study of the dimensional stability of the specimens has been carried out (in accordance with UNE 83831: 2010 EX) characterized by the study of the lengths and initial masses of mortar specimens and specific variation thereof, in $\%$ deformation, at 7, 14 and 28 days.

Similarly, the mean bulk densities of dry mortars were determined by calculating the masses and volumes of specimens applying the EN 1015-10: 2000 standard.

Also, carbonation of portlandite level was determined according to EN 13295, measuring the depth of carbonation reached by the samples in a period of 60 days $(33,34)$. To this end, after fracturing different specimens with a press to obtain two regular, flat surfaces, all residual dust was eliminated from the fractured surfaces and a $1 \%$ solution of phenolphthalein was sprayed on them. Carbonated areas did not change color, while areas with $\mathrm{pH}$ higher than 9 acquired a bright fuchsia color due to $\mathrm{OH}^{-}$ presence of portlandite phase. This color change shows the depth of the carbonation front.

After this, a digital photograph (Figure 1) was taken using a macro, trying to capture the real magnitude of the treated surface. This photograph was inserted into a Computer Assisted Design (CAD) program to draw a series of polylines referring to the outlines of the different specimens $(\mathrm{S})$ and the carbonation surfaces $\left(\mathrm{S}_{\mathrm{c}}\right)$ (Figure 1). Once the calculation of both areas was performed, the percentage of carbonate surface was possible to be determined.

A mean theoretical depth of carbonation $\left(\mathrm{P}_{\mathrm{c}}\right)$ was estimated. In this way, and taking into account that the supporting side of the specimen had not

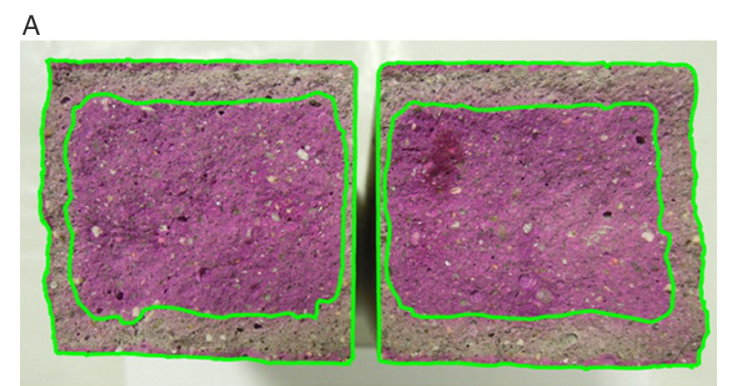

B

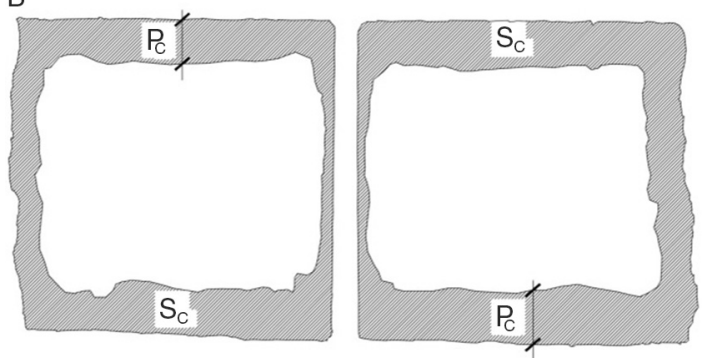

FIGURE. 1. Graphic procedure for calculating the carbonated surface.

suffered any direct carbonation process, the active perimeter of carbonation was estimated to be of $120 \mathrm{~mm}$ linear (corresponding to the other three exposed faces), and therefore [2]:

$$
P_{c}=\frac{S_{c}}{120}
$$

Being:

Pc: Mean theoretical carbonation depth (mm).

Sc: Calculated carbonation surface $\left(\mathrm{mm}^{2}\right)$.

To finish the physical/mechanical tests, mechanical strengths, in $\mathrm{N} / \mathrm{mm}^{2}$, were determined, calculating the mean values of both ultimate bending and compression strengths at 7, 28,60 and 90 days (EN 1015-11: 2000).

\subsubsection{X-Ray diffraction}

X-ray diffraction has been performed on the fly ash samples in order to determine the different crystalline phases so as to define the possible uses of fly ash, using the powder method by means of Siemens D-5000 diffractometer. Likewise, treated fly ashes were also analyzed in the same way in order to test the complete carbonation process.

The diffraction diagram has been in the range of $2 \theta\left[5.00^{\circ}\right.$ a $\left.100.00^{\circ}\right]$, with a step of $\Delta(2 \theta)=0.04^{\circ}$ and a time of 4 seconds per step. $\mathrm{K} \alpha$ del $\mathrm{Cu}=1.5418 \AA$ has been used.

\subsubsection{Leaching tests}

The leaching test analysis of hardened specimens was carried out at the age of 28 days. According to previous researches on the matter related to 
monolithic mortars $(17,26,35,36)$ it was decided to run the French standard NF P X31-211 on mortars of the best mechanical performance. Both specimens, reference mortar and treated ash mortar, were sawed in $4 \times 4 \times 4 \mathrm{~cm}^{3}$ prisms. The test referred consists of one leaching cycle of $24 \mathrm{~h}$ in stirred deionized water. The liquid to solid ratio was set to 10 , which makes $96 \mathrm{~cm}^{2}$ exposed surface area for $640 \mathrm{ml}$ of water. $\mathrm{Zn}, \mathrm{Pb}, \mathrm{Cu}$ and $\mathrm{Cd}$ measurements on the leachate collected after filtration through a $0.45 \mu \mathrm{m}$ filter were performed by stripping voltammetry determination. In order to check the heavy metal content in lixiviate, $\mathrm{Cu}^{2+}$ was analyzed as a level indicator example of non-amphoteric heavy cation. Amphoteric $\mathrm{Zn}^{2+}$ and $\mathrm{Pb}^{+2}$ are also controlled being $\mathrm{Cd}^{2+}$ a cation test.

\section{RESULTS AND DISCUSSION}

\subsection{Fly ash stabilization process}

\subsubsection{Search of possible reagents to be used in the stabilization process}

A search of the possible reagents has been carried out to use them in the stabilization process of fly ash, taking into account its heavy metal content. To this end, literature has been reviewed finding various anions that would react with the present soluble heavy metals and, that would generate an insoluble precipitate (24). The most important data to take into account is the $25^{\circ} \mathrm{C}$ solubility product, defined by the neutral water equilibrium constant for the reaction of the compound dissolution $\left(\mathrm{B}_{\mathrm{y}} \mathrm{C}_{\mathrm{x}}\right)[3]$ :

$$
\mathrm{B}_{\mathrm{y}} \mathrm{C}_{\mathrm{x}(\mathrm{s})} \mathrm{D} \mathrm{yB}^{\left.\mathrm{x}-{ }_{(\text {aq. }}\right)}+\mathrm{xC}^{\mathrm{y}+} \text { (aq.) }
$$

In this way, considering previous researches $(25,26)$ aiming to stabilize heavy metals and, at the same time to eliminate part of chlorides of fly ash through washing, an alternative method using $\mathrm{NaHCO}_{3}$ is established. An appropriate combination of this will exercise a buffer function and maintain $\mathrm{pH}$ at an optimum value, for which the heavy metals content in the leachate will be minimal. Likewise, the addition of $\mathrm{Na}^{+}$ion in equivalent quantities to chloride ions, in the fly ash washing process, will facilitate the removal of a large amount of chlorides in the form of sodium chloride. In addition, $\mathrm{NaHCO}_{3}$ is a cheap and safe stabilizing agent and does not alter the $\mathrm{pH}$ of cementitious materials.

\subsubsection{Determining $\mathrm{NaHCO}_{3}$ quantity to be used in the stabilization reaction}

In order to eliminate most of the chloride from the fly ash, the equivalent number of it will be taken as reference to determine the equivalent sodium required and to complete the elimination of chloride.
At the same time, the $\mathrm{CO}_{3}^{2-}$ anion carbonate reacts with the existing heavy metals ions to form insoluble carbonates.

In order to quantify the chloride content, a weighed ash amount is completely dissolved in diluted nitric acid and subsequently the free chloride ion is quantified by potentiometric silver titration. The number of gram-equivalent obtained per mass unit will also be the number of gram-equivalents of $\mathrm{NaHCO}_{3}$ used per mass unit $\left(127 \mathrm{mg}\right.$ of $\mathrm{Cl}^{-} / \mathrm{gr}$ of fly ash sample or $3.24 \mathrm{Eq} / \mathrm{Kg} \mathrm{de} \mathrm{Cl}^{-}$).

\subsection{Characteristics of the fly ash (FA \& TFA)}

\subsubsection{Chemical composition of MSWI fly ash}

Analytical data in Table 2 shows a high content of heavy metals in original fly ashes, mainly regarding $\mathrm{Zn}$ and $\mathrm{Pb}$ content and also high levels of chlorides. The problem arising from $\mathrm{Cl}^{-}$ion excess in cementations mixtures is the one derived from corrosion. On the one hand, depassivation chloride ions generate a fast pitting corrosion which locally erodes the reinforcement that may exist (both on the structural one and on those designed to prevent surface cracks) (37). On the other hand, there is a reaction of $\mathrm{Ca}(\mathrm{OH})_{2}$ (portlandite) to form solid $\mathrm{Ca}(\mathrm{OH}) \mathrm{Cl}$ (calcium hydroxychloride). In this way, $\mathrm{Ca}(\mathrm{OH})_{2}$ stops reacting with silica, and a mortar $\mathrm{pH}$ decrease is produced. Uniform corrosion is the consequence of $\mathrm{pH}$ decrease and could destroy the passive film that protects steel reinforcement. In this case, the combination of both possibilities (decrease in $\mathrm{pH}$ and chloride excess) could lead to a dramatic general corrosion.

Two goals are achieved through the treatment with the $\mathrm{NaHCO}_{3}$ solution. Firstly, the soluble heavy metal ions existing in the original ashes, due to chloride presence, are transformed into poor soluble solid carbonate or hydroxide precipitates. Secondly, the content of chlorides has been drastically reduced in almost 99\% but, despite this, their use is not recommended with steel reinforcing rods (38). An advantage of this process of washing and treatment of fly ash from MSWI is that, along with water from the washing, almost all of the original $\mathrm{Cl}^{-}$is eliminated due to the formation of a soluble non-polluting waste such as $\mathrm{NaCl}$ (sodium chloride solution). With the solution addition of sodium bicarbonate to the washing process, all heavy metal ions are transformed into non soluble carbonates and, at the same time, the $\mathrm{Na}^{+}$provided by them reacts forming $\mathrm{NaCl}$ solution.

\subsubsection{X-Ray diffraction}

FA XRD analysis is shown in Figure 2. The diffraction diagram shows broad and low intensity diffraction peaks, characteristic of a poor crystallized material. Two crystalline phases have been clearly 
TABLE 2. Chemical composition of the original MSWI fly ash (FA) and the treated MSWI fly ash (TFA)

\begin{tabular}{|c|c|c|c|c|c|}
\hline & \multicolumn{2}{|c|}{ Primary elements $(\mu \mathrm{g} / \mathrm{g})$} & & \multicolumn{2}{|c|}{ Primary elements (\%) } \\
\hline & FA & TFA & & FA & TFA \\
\hline $\mathrm{Zn}$ & $4492 \pm 232$ & $4065 \pm 210$ & $\mathrm{Cl}^{-}$solubles & $11 \pm 2$ & $0.12 \pm 0.02$ \\
\hline $\mathbf{P b}$ & $1026 \pm 51$ & $876 \pm 44$ & $\mathbf{C a}$ & $33 \pm 1$ & $28 \pm 1$ \\
\hline Mn & $315 \pm 31$ & $530 \pm 30$ & Si & $4.2 \pm 0.2$ & $7.7 \pm 0.4$ \\
\hline Sn & $351 \pm 18$ & $455 \pm 23$ & $\mathbf{S}$ & $1.38 \pm 0.08$ & $0.85 \pm 0.05$ \\
\hline $\mathbf{P}$ & $5005 \pm 310$ & $4900 \pm 300$ & Al & $2.23 \pm 0.20$ & $3.55 \pm 0.36$ \\
\hline $\mathrm{Cr}$ & $242 \pm 24$ & $470 \pm 47$ & Mg & $0.94 \pm 0.09$ & $1.0 \pm 0.1$ \\
\hline $\mathbf{N i}$ & $93 \pm 9$ & $146 \pm 15$ & $\mathrm{Fe}$ & $0.79 \pm 0.05$ & $1.50 \pm 0.1$ \\
\hline $\mathrm{Cu}$ & $330 \pm 17$ & $266 \pm 13$ & $\mathbf{T i}$ & $0.40 \pm 0.01$ & $0.60 \pm 0.06$ \\
\hline $\mathbf{B a}$ & $412 \pm 30$ & $806 \pm 60$ & $\mathbf{N a}$ & $0.84 \pm 0.04$ & $0.28 \pm 0.01$ \\
\hline Sb & $372 \pm 19$ & $322 \pm 16$ & $\mathbf{K}$ & $3.1 \pm 0.3$ & $0.65 \pm 0.15$ \\
\hline Cd & $60 \pm 3$ & $52 \pm 3$ & Sulfates $(\mathrm{mg} / \mathrm{L})$ & $<2500$ & \\
\hline $\mathrm{Sr}$ & $361 \pm 25$ & $349 \pm 24$ & & & \\
\hline $\mathbf{W}$ & $8.2 \pm 0.8$ & $8.1 \pm 0.8$ & & & \\
\hline $\mathbf{Z r}$ & $73 \pm 5$ & $114 \pm 8$ & & & \\
\hline As & $<25$ & $<25$ & & & \\
\hline Co & $9.2 \pm 0.9$ & $14 \pm 1$ & & & \\
\hline Mo & $8.3 \pm 0.8$ & $9.4 \pm 0.9$ & & & \\
\hline $\mathbf{B i}$ & $<5.0$ & $<5.0$ & & & \\
\hline $\mathrm{Ce}$ & $18 \pm 1$ & $30 \pm 2$ & & & \\
\hline $\mathbf{G a}$ & $<25$ & $<25$ & & & \\
\hline $\mathbf{L a}$ & $10.4 \pm 0.5$ & $15.3 \pm 0.8$ & & & \\
\hline Nd & $8.1 \pm 0.6$ & $11.9 \pm 0.8$ & & & \\
\hline Nb & $6.1 \pm 0.6$ & $8.9 \pm 0.9$ & & & \\
\hline
\end{tabular}

identified: $\mathrm{Ca}(\mathrm{OH})_{2}$ and $\mathrm{Ca}(\mathrm{OH}) \mathrm{Cl}$. The X-ray diffraction diagram was refined using the Rietveld method, in which:

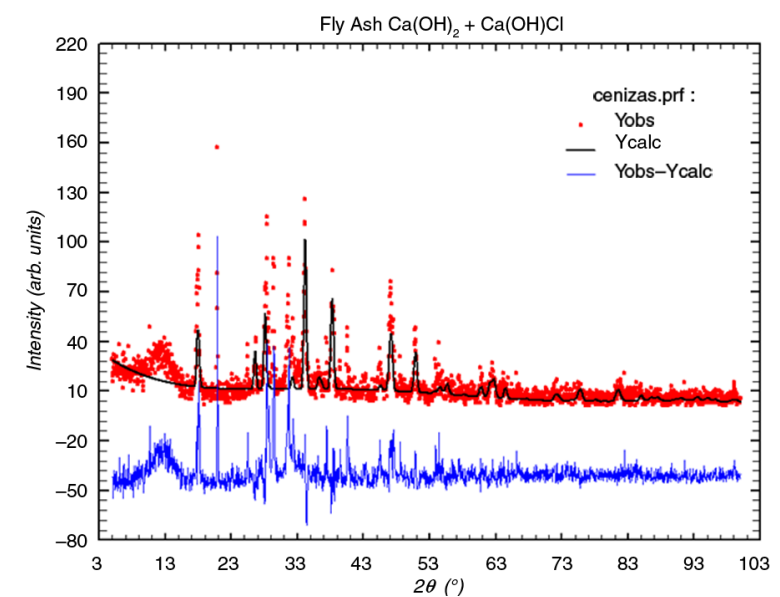

FIGURE 2. X-ray diffraction diagram of fly ash. Red dot are experimental data, continuous black line is the calculated diagram, bottom blue line are the difference between experimental and calculated data. Vertical green lines corresponds to the bragg position of $\mathrm{Ca}(\mathrm{OH})_{2}$ and $\mathrm{Ca}(\mathrm{OH}) \mathrm{Cl}$ phases.
Figure 3 shows XRD analysis of TFA. The diffraction diagram shows one crystalline phase clearly identified: Calcite $\left(\mathrm{CaCO}_{3}\right)$. The evidence proves that successful carbonation of the samples was achieved.

\subsubsection{Differencial Scanning Calorimetry and Thermogravimetry}

Differential scanning calorimetry and thermogravimetry (DSC-TGA) was used to study the type of decomposition process in FA and TFA ashes. Figure 4 shows FA curves in which several endothermic reactions according to two main signals are appreciated. The first signal, between $368^{\circ} \mathrm{C}$ and $501{ }^{\circ} \mathrm{C}$, is mainly due to the superposed decomposition of Calcium Hydroxide - $\mathrm{Ca}(\mathrm{OH})_{2}$ - and calcium hydroxychloride - $\mathrm{CaClOH}$ - (39-41) which will overlap with the combustion of some organic matter content in the FA (40-42). The second signal, between $596^{\circ} \mathrm{C}$ and $716^{\circ} \mathrm{C}$, is in accordance with the decomposition of carbonates, particularly calcium carbonate (41). Above $830{ }^{\circ} \mathrm{C}$, a slight decomposition of well-crystallized carbonates occurs (43).

Figure 5 shows one clear endothermic peek between $636^{\circ} \mathrm{C}$ and $805^{\circ} \mathrm{C}$ in the DSC-TGA signal 


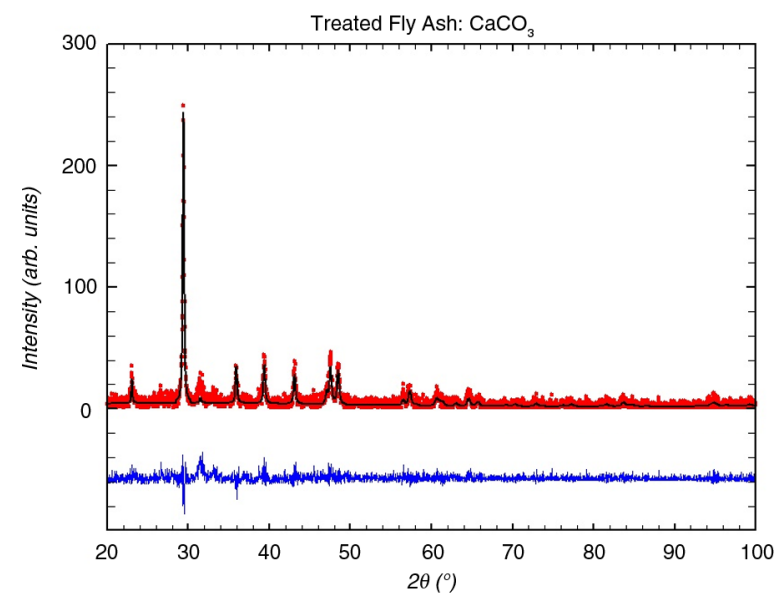

FIGURE 3. X-ray diffraction diagram of the treated fly ash (TFA) Red dot are experimental data, continuous black line is the calculated diagram, bottom blue line are the difference between experimental and calculated data. Vertical blue lines corresponds to the bragg position of $\mathrm{CaCO}_{3}$ phase.

for TFA. This fact allows precise identification of the hydrated phase according to the characteristic of decarbonation which shows a correlation between the weight loss and the size of the peek $(40,41)$. Therefore full carbonation of TFA is confirmed from the DSC analysis.

\subsection{Water proportion in mortars}

In Table 3, results of water/cement ratios for all tested mortars are show. In every case, except in 1/1 proportion of mortars performed with CAC, the addition of TFA in mortars considerably increases the water needed to maintain the workability of the batch. In the case of CAC mortars, this will be directly related with the compressive strength values.
In the analyses carried out so far, the $\mathrm{Zn}$ and $\mathrm{Pb}$ content stabilized in the form of carbonates, does not produce a delay in the setting (44). As seen in Table 2, these two metals are present in fly ash and, nevertheless, setting time acceleration is produced in all mortars studied, possibly because they appear in the form of carbonates.

Finally, when comparing the water/cement ratio used in the preparation of samples shown in Table 3, with the results of the setting time of Figure 6, a reduced workability of both CAC cement mortars with the incorporation of TFA can be observed. This could cause an increase in compressive strength based on the water absorption during the preparation of the batch. This absorption of water decreases the effectiveness of water/cement ratio causing an increase in strength.

\subsection{Dimensional stability}

Table 4 shows the results of dimensional stability of the mortars made with CEM-I and 1/1 proportion. Mortars with ash additions have a higher percentage of contraction than that of the reference mortar, being TFA mortars where larger strains can be appreciated, although the deformations remain constant throughout the testing process. Conversely, mortars with some kind of fly ash present a smaller mass loss than their reference counterparts.

Table 4 also provides the results of CEM-I mortars in a1/3 proportion. Strain of TFA mortars are slightly lower than those developed in proportion $1 / 1$, although comparing it with the reference mortar, it is worse, since it remains virtually unchanged. The mass loss of TFA mortars with CEM-I and proportion $0 / 2$ is higher than $8 \%$ with regard to the reference mortars.

Table 4 shows the dimensional stability data of the mortars made with CEM-II. Strains observed

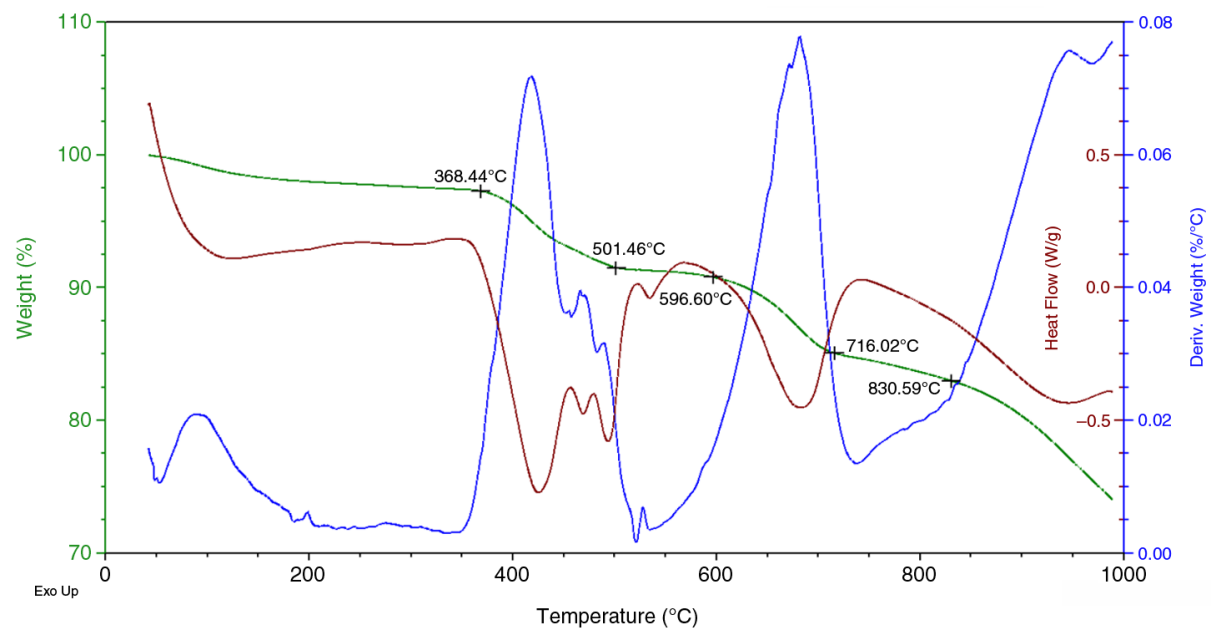

FIGURE 4. DSC-TGA curves for FA samples. 


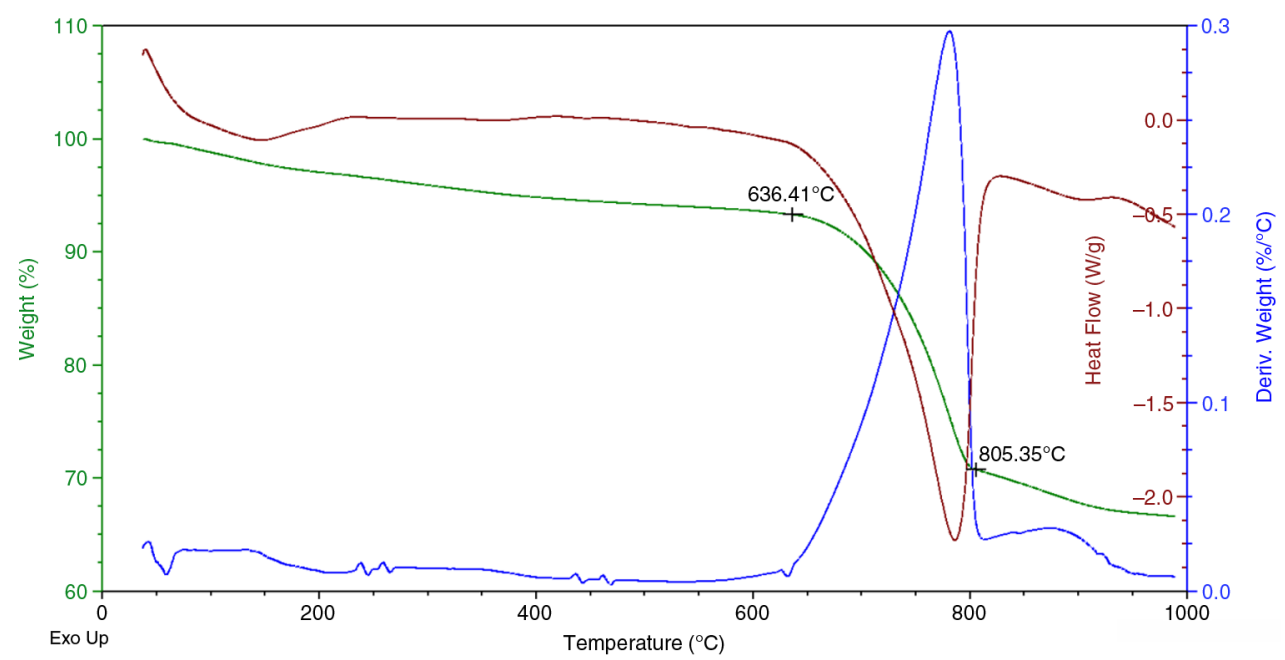

Figure 5. DSC-TGA curves for TFA samples.

in TFA mortars, just as with the other type of Portland cement, are the highest in both proportions $(1 / 1$ and $1 / 3)$ with data from $0.19 \%$ and $0.20 \%$. However, once again the trend is repeated, since they offer relative stability in their behavior being very similar in both cases. The specific mass variation at $1 / 1$ and $1 / 3$ proportions presents some very similar behavioral schemes, but with best performance in $1 / 1$ mortars.

Dimensional stability data of mortars made with CAC are also shown on Table 4. Data provided by mortars with this type of cement for the $1 / 1$ proportion

TABLE 3. Water/Cement ratio of the tested mortars

\begin{tabular}{lccccc}
\hline & & \multicolumn{3}{c}{ Mortar } \\
\cline { 3 - 6 } Cement & Aggregate & Proportion & $\mathbf{R}$ & FA & TFA \\
\hline \multirow{4}{*}{ CEM I } & \multirow{2}{*}{$0 / 2$} & $1 / 1$ & 0.38 & 0.43 & 0.50 \\
& & $1 / 3$ & 0.68 & 0.77 & 0.90 \\
& \multirow{2}{*}{$0 / 4$} & $1 / 1$ & 0.40 & 0.44 & 0.50 \\
& & $1 / 3$ & 0.64 & 0.73 & 0.86 \\
CEM II & $0 / 2$ & $1 / 1$ & 0.36 & 0.41 & 0.47 \\
& & $1 / 3$ & 0.70 & 0.77 & 0.88 \\
& $0 / 4$ & $1 / 1$ & 0.36 & 0.39 & 0.44 \\
& & $1 / 3$ & 0.64 & 0.73 & 0.82 \\
CAC & $0 / 2$ & $1 / 1$ & 0.42 & 0.78 & 0.34 \\
& & $1 / 3$ & 0.66 & 1.05 & 0.80 \\
& $0 / 4$ & $1 / 1$ & 0.40 & - & 0.34 \\
& & $1 / 3$ & 0.60 & - & 0.74 \\
CSA & $0 / 2$ & $1 / 1$ & 0.40 & 0.50 & 0.48 \\
& & $1 / 3$ & 0.68 & 0.74 & 0.80 \\
& $0 / 4$ & $1 / 1$ & 0.40 & 0.46 & 0.50 \\
& & $1 / 3$ & 0.64 & 0.70 & 0.76 \\
\hline
\end{tabular}

are very positive. Both deformation and specific mass variation results exceed the reference mortars ones. This mortar turns out to be the one with greater dimensional stability of all the ones studied. Data for $1 / 3$ proportion can also be considered as a good relative value, although they are below those offered by the reference mortars at all times.

Table 4 finally provides dimensional stability data of mortars made with CSA. Deformations in both types of proportions are particularly positive. Not only does the trend mark a conservation of dimensional stability, unlike reference mortars, but also the values offered at 28 days are the best ones obtained with this type of mortars and of all the ones tested. Nevertheless, a greater specific mass loss is observed with values below those offered by the reference mortar.

In all cases studied, the high content of chlorides and sulphates of MSWI fly ash can produce the formation of large quantities of Ettringite and Chloroaluminate, mobilizing a large amount of water molecules. The early formation of any of these hydrates could explain the dry shrinkage of mortar containing fly ash at early stages.

As a supplementary analysis to the one on dimensional stability, Table 4 presents the density results of the dry mortar samples studied. In all cases, except for the CAC mortars and proportion $1 / 1$, a gradual material lightening occurs when TFA are added. In CEM-I mortars, the decrease in the material density is around $11 \%$. Mortar with CEM-II lightening is $10 \%$, and for those performed with CSA, lightening is reduced by $4.5 \%$ for $1 / 1$ proportion, and by 6.5 percent for the $1 / 3$ proportion. Especially interesting is the case of the CAC mortars in a $1 / 1$ proportion, in which the trend is reversed and a minimum density increase of $3.5 \%$ takes place. 
10 • O. López-Zaldívar et al.

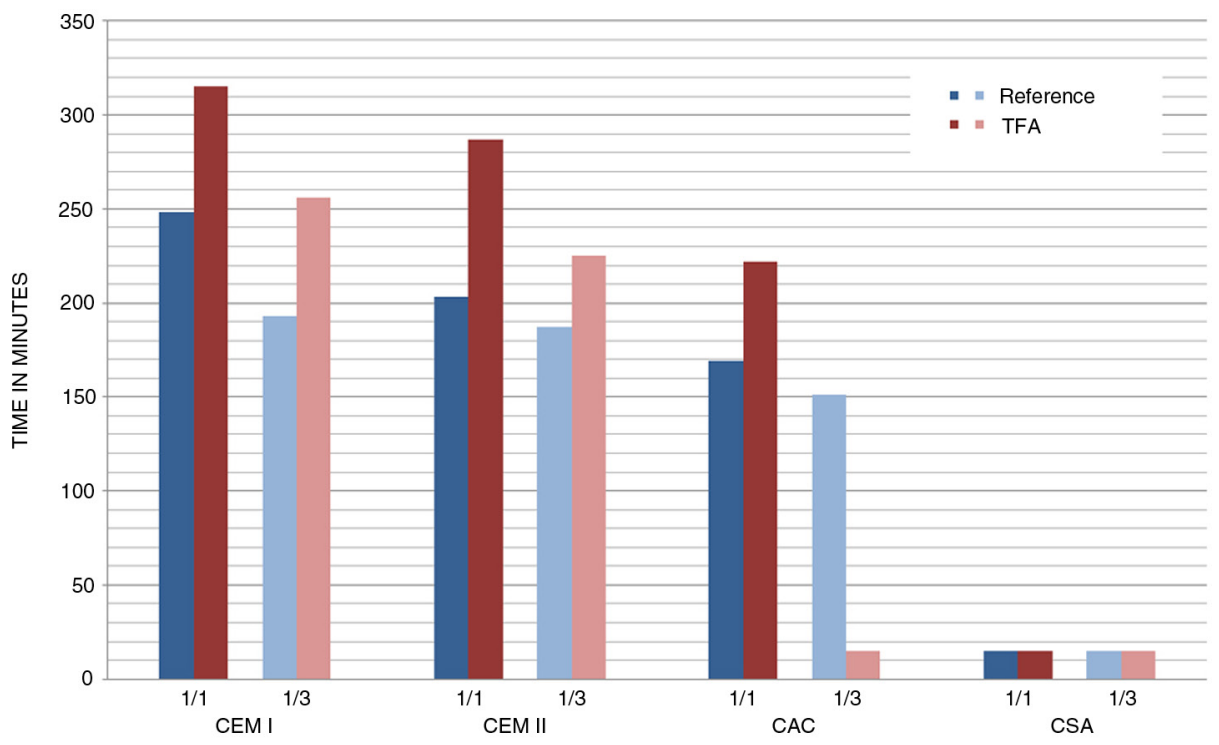

FIGURE 6. Workability period, in minutes, for common use mortars tested.

TABLE 4. Dimensional stability of the mortars. Variation of the specific length (strain) $(\Delta \mathrm{L}(\varepsilon))(\%)$ and variation of the specific weight $(\Delta \mathrm{m})(\%)$. Mean bulk density when dry $\left(\rho_{\text {mean }}\right)$ of hardened mortar $\left(\mathrm{kg} / \mathrm{m}^{3}\right)$. $(\mathrm{R})$ Reference mortars without treated fly ash. (TFA) Mortars replacing $10 \%$ of the aggregate with treated fly ash

\begin{tabular}{|c|c|c|c|c|c|c|c|c|}
\hline \multirow[b]{2}{*}{ Cement } & \multirow[b]{2}{*}{ C/W } & & \multicolumn{2}{|c|}{7 days } & \multicolumn{2}{|c|}{14 days } & \multicolumn{2}{|c|}{28 days } \\
\hline & & & $\mathbf{R}$ & TFA & $\mathbf{R}$ & TFA & $\mathbf{R}$ & TFA \\
\hline \multirow{6}{*}{ CEM I } & \multirow{3}{*}{$1 / 1$} & $\Delta \mathrm{L}(\varepsilon)$ & -0.16 & -0.26 & -0.14 & -0.26 & -0.20 & -0.28 \\
\hline & & $\Delta \mathrm{m}$ & -2.78 & -4.62 & -2.90 & -4.67 & -3.03 & -4.91 \\
\hline & & $\rho_{\text {mean }}$ & & & & & 2016.20 & 1795.45 \\
\hline & \multirow{3}{*}{$1 / 3$} & $\Delta \mathrm{L}(\varepsilon)$ & -0.05 & -0.23 & -0.05 & -0.23 & -0.60 & -0.24 \\
\hline & & $\Delta \mathrm{m}$ & -5.14 & -7.44 & -5.56 & -7.95 & -5.72 & -8.32 \\
\hline & & $\rho_{\text {mean }}$ & & & & & 1945.40 & 1764.15 \\
\hline \multirow{6}{*}{ CEM II } & \multirow{3}{*}{$1 / 1$} & $\Delta \mathrm{L}(\varepsilon)$ & -0.11 & -0.15 & -0.14 & -0.15 & -0.14 & -0.19 \\
\hline & & $\Delta \mathrm{m}$ & -3.23 & -4.12 & -3.55 & -4.82 & -3.79 & -5.03 \\
\hline & & $\rho_{\text {mean }}$ & & & & & 1975.80 & 1798.62 \\
\hline & \multirow{3}{*}{$1 / 3$} & $\Delta \mathrm{L}(\varepsilon)$ & -0.06 & -0.16 & -0.05 & -0.16 & -0.09 & -0.20 \\
\hline & & $\Delta \mathrm{m}$ & -7.15 & -8.32 & -7.48 & -9.55 & -7.64 & -9.72 \\
\hline & & $\rho_{\text {mean }}$ & & & & & 1969.02 & 1761.21 \\
\hline \multirow{6}{*}{ CAC } & \multirow{3}{*}{$1 / 1$} & $\Delta \mathrm{L}(\varepsilon)$ & -0.03 & -0.14 & -0.06 & -0.14 & -0.05 & -0.04 \\
\hline & & $\Delta \mathrm{m}$ & -0.58 & -0.18 & -0.81 & -0.26 & -1.04 & -0.31 \\
\hline & & $\rho_{\text {mean }}$ & & & & & 2127.64 & 2201.12 \\
\hline & \multirow{3}{*}{$1 / 3$} & $\Delta \mathrm{L}(\varepsilon)$ & -0.06 & -0.07 & -0.04 & -0.07 & -0.02 & -0.10 \\
\hline & & $\Delta \mathrm{m}$ & -1.22 & -2.53 & -1.65 & -3.03 & -2.15 & -3.53 \\
\hline & & $\rho_{\text {mean }}$ & & & & & 2070.18 & 1960.16 \\
\hline \multirow{6}{*}{ CSA } & \multirow{3}{*}{$1 / 1$} & $\Delta \mathrm{L}(\varepsilon)$ & -0.06 & -0.06 & -0.07 & -0.06 & -0.11 & -0.04 \\
\hline & & $\Delta \mathrm{m}$ & -0.59 & -1.62 & -0.48 & -1.80 & -0.54 & -1.85 \\
\hline & & $\rho_{\text {mean }}$ & & & & & 1971.20 & 1883.59 \\
\hline & \multirow{3}{*}{$1 / 3$} & $\Delta \mathrm{L}(\varepsilon)$ & 0.00 & -0.06 & -0.03 & -0.06 & -0.06 & -0.02 \\
\hline & & $\Delta \mathrm{m}$ & -3.12 & -4.58 & -3.26 & -4.81 & -3.33 & -4.89 \\
\hline & & $\rho_{\text {mean }}$ & & & & & 1990.09 & 1863.94 \\
\hline
\end{tabular}




\subsection{Carbonation}

The study of carbonation in the tested samples is very important regarding heavy metal encapsulation, as opposed to what was initially expected: it is very useful in reducing heavy metal leaching. In fact, (45), conclude that the carbonation process can be used as a pre-treatment for the retention of heavy metals, while a series of MSWI fly ash washings are carried out to remove soluble salts.

Table 5 shows the mean value of six data gatherings for each analyzed sample, data concerning the percentage of carbonate surface, regarding the total fracture surface of each of the mortar specimens tested. The carbonation process is further stressed when the mortar is more porous and the amount of carbon dioxide in the atmosphere is greater. All specimens have been exposed to the same environmental conditions; this implies that these analyses are a clear indicator of the porosity of the mortars tested. However, another process that greatly influences carbonation is the degree of saturation, and given that $\mathrm{CO}_{2}$ diffusion throughout the mortar internal structure is only possible through air-filled pores, the maximum acceleration in the process can be reached when there is a balance between the occluded air in the mortar matrix and the moisture degree in it. Therefore, in these results, the mixing water used in each of the mortars (Table 3 ) needs to be considered and to be related to each other.

Regarding ordinary Portland cement mortars, those made with CEM-I and proportion 1/1, present a very homogeneous stain of phenolphthalein, with a very bright fuchsia color and a very well-defined rectilinear perimeter parallel to the surface. Carbonation depth increases proportionally, at both $1 / 1$ and $1 / 3$ proportions, while fly ash is being added to the mixture. Maximum carbonation depths are reached with TFA mortars; something logical since fly ash is added in the form of calcium carbonate.

TABLE 5. Carbonated surface Sc (\%) and theorical carbonation depth, Pc (mm)

\begin{tabular}{|c|c|c|c|c|c|c|}
\hline \multirow[b]{3}{*}{ Cement } & \multirow[b]{3}{*}{ Aggregate } & \multirow[b]{3}{*}{ Proportion } & \multicolumn{4}{|c|}{ Mortar } \\
\hline & & & \multicolumn{2}{|c|}{$\mathbf{R}$} & \multicolumn{2}{|c|}{ TFA } \\
\hline & & & $\begin{array}{c}S_{c} \\
(\%)\end{array}$ & $\begin{array}{c}\boldsymbol{P}_{c} \\
(\mathrm{~mm})\end{array}$ & $\begin{array}{c}S_{c} \\
(\%)\end{array}$ & $\begin{array}{c}\boldsymbol{P}_{c} \\
(\mathrm{~mm})\end{array}$ \\
\hline \multirow{2}{*}{ CEM I } & \multirow{2}{*}{$0 / 2$} & $1 / 1$ & 7.59 & 1.012 & 10.83 & 1.445 \\
\hline & & $1 / 3$ & 16.65 & 2.220 & 19.97 & 2.662 \\
\hline \multirow{2}{*}{ CEM II } & \multirow{2}{*}{$0 / 2$} & $1 / 1$ & 11.00 & 1.466 & 12.03 & 1.604 \\
\hline & & $1 / 3$ & 16.00 & 2.133 & 23.47 & 3.129 \\
\hline \multirow{2}{*}{ CAC } & \multirow{2}{*}{$0 / 2$} & $1 / 1$ & 19.80 & 2.641 & 19.67 & 2.623 \\
\hline & & $1 / 3$ & 26.68 & 3.558 & 57.71 & 7.695 \\
\hline \multirow{2}{*}{ CSA } & \multirow{2}{*}{$0 / 2$} & $1 / 1$ & 37.97 & 5.062 & 56.83 & 7.577 \\
\hline & & $1 / 3$ & 46.54 & 6.206 & 75.22 & 10.03 \\
\hline
\end{tabular}

For CEM-I and $1 / 3$ proportion, carbonation depths are close to the double of those obtained for $1 / 1$ proportion. Rounded corners on the indicator stain can be seen, and part of it shows small carbonated sections, while regularity and parallelism at the edges are maintained. TFA mortars can be highlighted because their carbonation process occurs in a much more homogeneous way than the reference mortar, despite having a somewhat higher carbonation depth. In ordinary Portland cement mortars, the amount of $\mathrm{CaCO}_{3}$ present in the TFA favors carbonation speed (45).

CEM-II samples maintain the same pattern regarding the phenolphthalein stain than those samples performed with CEM-I, despite having greater carbonation depths. In this case, the inclusion of TFA in the $1 / 1$ proportion is to be commented, as it causes a decrease in the depth of the carbonation front which comes closely to the levels of the of the reference mortar.

CAC mortars present in both proportions a very irregular phenolphthalein stain with many peaks. In the reference mortar the color of the indicator is bright pink, whereas, the TFA mortar presents a much more diffused color, which indicates a very advanced internal carbonation process. Carbonation depth in TFA mortars with $1 / 1$ proportion are virtually identical to the reference mortar one, although the carbonation speed of the central area of the specimen is much greater in the former mortars.

Unlike reactions produced in Portland cement mortars, in which the appearance of calcium carbonate $\left(\mathrm{CaCO}_{3}\right)$ is produced by the transformation of calcium hydroxide $\left(\mathrm{Ca}\left(\mathrm{OH}_{2}\right)\right)$ in aluminous cements, the affected products will be hydrated calcium aluminates which will produce aluminum hydroxide, in addition to calcium carbonate. This process together with the fact that alkalinity and the initial $\mathrm{pH}$ of aluminate cements are lower than that of Portland cement, favors carbonation. However, carbonation does not entail a decrease in strength. Carbonation generates a reduction of mortar porosity due to the precipitation in the existing pores of the products originated in the reaction, and therefore, a slight increase in strength is produced.

Regarding CSA mortars, they present much higher rates of carbonation compared with both Portland and CAC cements. For CSA mortars with proportion $1 / 3$, as well as for TFA mortars of proportion $1 / 1$, a singular feature is observed: i.e. the carbonation front does not start on the surface, but gets in gradually. In this case, an area of surface protection, which is not carbonated, can be seen; this area is much more pronounced in the reference mortar. This fact may be due to the characteristics of the used cement. This cement is produced in a similar process to that of Portland cement but with less energy consumption, different configuration phases and similar or higher mechanical properties than that other cement. 
CSA cements present a rapid hydration, which can generate a very heterogeneous distribution of pores and therefore, a higher carbonation, which in turn, has been accelerated with the addition of TFA resulting in a total carbonation of the studied surfaces.

In all cases studied, the inclusion of TFA implies an increase in the porosity of the resulting mortar. However, as it occurs in the section concerning strengths, this does not affect the final compressive strengths. Similarly, verifying that the carbonation process significantly reduces the values of $\mathrm{Pb}$ and $\mathrm{Zn}$ leachate is needed (45).

\subsection{Strengths}

Results of mechanical compressive strengths of mortars made with CEM-I are presented in Table 6. Similar behaviors can be seen for $1 / 1$ and $1 / 3$ proportions. In both cases, the inclusion of treated fly ash considerably reduces strengths obtained in relation to the reference mortars $(19.79 \%$ and $25.44 \%$, respectively). In this case, through the process carried out by washing with sodium hydrogen carbonate $\left(\mathrm{NaHCO}_{3}\right)$ a transformation of hydroxides into inert carbonates occurs, especially calcium carbonate $\left(\mathrm{CaCO}_{3}\right)$.

Table 6 also shows the results of compressive strength for CEM-II mortars. Data are proportional to the ones observed for CEM-I mortars and quite close to the strengths provided, considering that CEM-II type has a $10 \mathrm{MPa}$ initial strength smaller than CEM-I. Again, mortars with TFA present strength declines of nearly $20 \%(22.72 \%$ and $17.27 \%$, respectively) while in this case, results are reversed since the greatest strength losses can be seen in proportion 1/1, in contrast with CEM-I mortars.

Another explanation of the strength loss is that this type of particle can be considered as a weaknesses within the mortar matrix. (46), showed that reactivity within mixtures of fly ash and cement pastes was particularly weak.

Compressive strength results of mortar made with CAC cements are presented in Table 6. The behavior of $1 / 1$ proportion mortar made with TFA is particularly noticeable. In each and every one of the studied ages, this cement shows strengths higher than the reference mortar, being particularly outstanding the data at 90 days, as it provides more than $25 \%$ higher compressive strength than the reference mortar. In the case of the $1 / 3$ proportion, the best data are achieved at 90 days, on a clear upward trend. Once again, results are practically $1.5 \%$ higher than those shown by the reference mortar.

On the other hand, despite having reduced almost $99 \%$ the content of chlorides in the treated ash, the presence of certain quantities of chlorides may also be the cause of an increase in strength. In fact, chlorides are known to have accelerating effects on the setting process (44).

Behavior regarding compression of CSA mortars is presented in Table 6. While the reference mortars show high initial strengths-although with a gradual strength loss at 28 and 60 days-two proportions, $1 / 1$ and $1 / 3$, made with TFA reverse this trend and present moderate initial strength but with a clear

TABLE 6. Mean value of ultimate compressive $\left(\mathrm{C}_{\mathrm{s}}\right)$ and bending $\left(\mathrm{B}_{\mathrm{s}}\right)$ strength of the mortars analyzed $\left(\mathrm{N} / \mathrm{mm}^{2}\right)$. (R) Reference mortars without treated fly ash. (TFA) Mortars replacing $10 \%$ of the aggregate with treated fly ash. (Particle size aggregates $0 / 2$ )

\begin{tabular}{|c|c|c|c|c|c|c|c|c|c|c|}
\hline \multirow[b]{2}{*}{ Cement } & \multirow[b]{2}{*}{ C/W } & & \multicolumn{2}{|c|}{7 days } & \multicolumn{2}{|c|}{28 days } & \multicolumn{2}{|c|}{60 days } & \multicolumn{2}{|c|}{90 days } \\
\hline & & & $\mathbf{R}$ & TFA & $\mathbf{R}$ & TFA & $\mathbf{R}$ & TFA & $\mathbf{R}$ & TFA \\
\hline \multirow{4}{*}{ CEM I } & \multirow{2}{*}{$1 / 1$} & $\mathrm{C}_{\mathrm{S}}$ & 69.46 & 54.45 & 81.92 & 62.23 & 87.74 & 67.77 & 86.46 & 69.42 \\
\hline & & $\mathrm{B}_{\mathrm{s}}$ & 10.350 & 8.911 & 9.154 & 8.863 & 11.235 & 8.354 & 10.909 & 8.782 \\
\hline & \multirow{2}{*}{$1 / 3$} & $\mathrm{C}_{\mathrm{s}}$ & 31.72 & 24.42 & 39.08 & 29.43 & 41.49 & 31.31 & 44.35 & 33.07 \\
\hline & & $\mathrm{B}_{\mathrm{s}}$ & 6.293 & 5.257 & 7.858 & 5.772 & 8.089 & 6.627 & 8.805 & 7.203 \\
\hline \multirow{4}{*}{ CEM II } & \multirow{2}{*}{$1 / 1$} & $\mathrm{C}_{\mathrm{s}}$ & 60.03 & 40.35 & 73.53 & 55.94 & 78.39 & 59.40 & 83.57 & 64.58 \\
\hline & & $\mathrm{B}_{\mathrm{s}}$ & 10.241 & 7.741 & 11.750 & 8.945 & 10.824 & 9.642 & 11.411 & 9.681 \\
\hline & \multirow{2}{*}{$1 / 3$} & $\mathrm{C}_{\mathrm{s}}$ & 21.41 & 17.51 & 26.85 & 22.77 & 37.49 & 26.96 & 33.45 & 27.67 \\
\hline & & $\mathrm{B}_{\mathrm{s}}$ & 5.521 & 4.404 & 6.058 & 5.225 & 8.114 & 5.871 & 7.340 & 6.818 \\
\hline \multirow{4}{*}{ CAC } & \multirow{2}{*}{$1 / 1$} & $\mathrm{C}_{\mathrm{s}}$ & 85.00 & 89.35 & 93.74 & 103.55 & 94.12 & 107.79 & 93.89 & 117.75 \\
\hline & & $\mathrm{B}_{\mathrm{s}}$ & 13.986 & 13.359 & 16.098 & 16.164 & 14.660 & 16.637 & 13.979 & 16.978 \\
\hline & \multirow{2}{*}{$1 / 3$} & $\mathrm{C}_{\mathrm{s}}$ & 58.52 & 40.82 & 58.27 & 46.09 & 51.93 & 43.41 & 44.87 & 45.42 \\
\hline & & $\mathrm{B}_{\mathrm{s}}$ & 6.789 & 6.195 & 6.479 & 7.766 & 6.847 & 7.718 & 6.717 & 8.730 \\
\hline \multirow{4}{*}{ CSA } & \multirow{2}{*}{$1 / 1$} & $\mathrm{C}_{\mathrm{s}}$ & 68.33 & 58.20 & 74.08 & 64.17 & 67.59 & 66.96 & 67.70 & 64.40 \\
\hline & & $\mathrm{B}_{\mathrm{s}}$ & 9.170 & 6.150 & 10.450 & 8.518 & 10.140 & 7.486 & 9.086 & 5.728 \\
\hline & \multirow{2}{*}{$1 / 3$} & $\mathrm{C}_{\mathrm{s}}$ & 49.63 & 28.60 & 46.48 & 32.37 & 43.91 & 35.43 & 28.90 & 31.21 \\
\hline & & $\mathrm{B}_{\mathrm{s}}$ & 6.387 & 4.635 & 5.439 & 4.551 & 5.575 & 4.538 & 5.045 & 5.103 \\
\hline
\end{tabular}


upward trend; in the case of the $1 / 1$ proportion of TFA showing even more than $1 \%$ higher values than those offered by the reference mortar. As a consequence, CSA present certain benefits in comparison with ordinary Portland cements (47). As it is a cement type with high initial strength, when used in combination with MSWI fly ash it promotes its stabilization/solidification in the mortar matrixes. Likewise, as previously said, the used ashes are rich in chlorides and sulfates, which may easily react with the calcium sulfoaluminate in the hydration process and take advantage of the new phases of this hydration to encapsulate heavy metals $(48,49)$. Similarly, the sulfide included in its initial formulation, will facilitate the precipitation of heavy metals contained in TFA in the form of sulfates.

Both CAC mortars, as well as CSA ones suffer higher carbonation rates. Aggregates, together with the evaporation of the mixing water lead to the development of a system of pores promoting $\mathrm{CO}_{2}$ diffusion. This fact, far from being negative, reduces shrinkage and cracking of the samples during drying and they can give rise to subsequent puzzolanic reactions favoring the increase of compressive strengths.

Finally, Table 6 also presents the results of bending strengths for all the mortars studied. Among them, CAC mortars with addition of TFA are particularly interesting. Proportions analyzed to date present an increase in strength of $21.46 \%$ and $29.96 \%$ compared to the reference mortar, reaching values of $16.978 \mathrm{~N} / \mathrm{mm}^{2}$ and $8.730 \mathrm{~N} / \mathrm{mm}^{2}$, respectively for $1 / 1$ and $1 / 3$ proportions. Likewise, CSA mortars made with TFA and $1 / 3$ proportion between cement and water, show a positive performance with regard to bending strengths, although to a minor extent. These data are very positive if the ultimate goal of this type of mortars is to be used in the manufacture of prefabricated pieces without structural reinforcement that must withstand its own shape and size, such as, for example, pipes for large collectors.

\subsection{Leaching tests}

Table 7 shows the results of the leaching test carried out on the mortars through stripping voltammetry determination. Leaching tests have been conducted on monolithic samples of the best mechanical performance mortar (CAC, aggregate 0/2, cement/water ratio $=1 / 1$ ).

As a result that cement mortars generate a solvent alkaline medium, $\mathrm{Zn}, \mathrm{Pb}, \mathrm{Cd}$ and $\mathrm{Cu}$ ions have been tested. Among them, only $\mathrm{Zn}$ and $\mathrm{Pb}$ quantities are significant because of their possibility to generate plumbite or zincate anions, whereas $\mathrm{Cd}$ and $\mathrm{Cu}$ have been measured just as a contrast. According to the shown data, only $\mathrm{Pb}$ ion slightly solubilizes and leachates, while the rest of the heavy metals ions analyzed remain at very low values (practically zero).
TABLE 7. Leaching values $(\eta \mathrm{g} / \mathrm{L})$ of the CAC mortars analyzed ( $\varnothing$ aggregate $0 / 2 ; \mathrm{C} / \mathrm{W}=1)$. (R) Reference mortars without treated fly ash. (TFA) Mortars replacing $10 \%$ of the aggregate with treated fly ash

\begin{tabular}{lcc}
\hline & \multicolumn{2}{c}{ Mortar type } \\
\cline { 2 - 3 } Element & $\mathbf{R}$ & TFA \\
\hline \multirow{2}{*}{$\mathrm{Zn}$} & 0.000 & 0.000 \\
& 5.0094 & 355.99 \\
& 0.000 & 1.356 \\
$\mathrm{Cd}$ & 164.11 & 618.56 \\
& 539.95 & 79.63 \\
& 129.65 & 45.78 \\
$\mathrm{~Pb}$ & 110.19 & 605.36 \\
& 372.92 & 650.1 \\
& 591.42 & 345.45 \\
$\mathrm{Cu}$ & 9.1667 & 0.0000 \\
& 0.0000 & 13.732 \\
& 0.0000 & 0.0000 \\
\hline
\end{tabular}

Therefore, the experimental results indicate that the shielding effect of the matrix of the CAC cement mortars encapsulates completely $\mathrm{Zn}$ ions and mitigates the leaching behavior of $\mathrm{Pb}$ ions.

\section{CONCLUSIONS}

- The mean data obtained on a sample period of 22 weeks indicates that the MSWI ashes have a high content of heavy metals, at least with regard to $\mathrm{Zn}$ and $\mathrm{Pb}$, and also high levels of chlorides and sulfates, making them to be treated as special waste.

- The washing method of the MSWI ashes with the appropriate $\mathrm{NaHCO}_{3}$ proportion shows a reduction of almost $99 \%$ of soluble chlorides. The addition of the $\mathrm{Na}+$ cation produces the elimination of these chlorides in the form of sodium chloride. The studied solution exerts the buffer function and maintains $\mathrm{pH}$ environment at the optimum values so that the concentration of heavy metals in the leachate is the minimum possible.

- CAC and CSA cement mortars with partial replacement of $10 \%$ of the aggregate with TFA, present much better behavior than CEM-I and CEM-II mortars, both in compressive strength and dimensional stability. CEM-I and CEM-II mortars with TFA present a clear compressive strength loss but with some technically acceptable values.

- CAC $1 / 1$ and $1 / 3$ and CSA $1 / 1$ mortars with TFA present compressive strength values even higher than the ones of the reference mortars. In the case of CAC 1/1 mortars, figures reach more than $25 \%$ higher than the reference values 
as well as more than $20 \%$ higher values regarding ultimate bending strength.

- CAC $1 / 1$ and CSA $1 / 1$ and 1/3 mortars with TFA present the best values of dimensional stability, in relation to the specific length loss, even higher than the values offered by the reference mortars in each of the cases.

- CAC 1/1 with TFA mortars present a minor decrease in specific weight. In contrast, it is the only mortar type, which increases its density with the incorporation of the treated fly ash.

- The results show that the workability period of mortars made with CAC $1 / 3$ and CSA cements and the inclusion of TFA is much shorter than those offered by the two types of ordinary Portland cement tested.

- In all analyzed mortars (except in CEM-I 1/1), the inclusion of TFA implies a carbonation increase of the resulting mortar and therefore, an increase in porosity. However, this does not seem to negatively affect final compressive strengths of the mortars made with CAC and CSA.

- The preparation of mortars for masonry uses with the partial replacement of aggregates in $10 \%$ by weight by treated fly ash used is theoretically possible. And, therefore, it is a viable method to achieve the stabilization/solidification of heavy metals present in them. The results indicate that the shielding effect of the matrix of the CAC cement mortars encapsulates $\mathrm{Zn}$ ions completely and mitigates the leaching behavior of $\mathrm{Pb}$.

From the above stated reasons, it might be concluded that mortars with the incorporation of treated fly ash made with CAC $1 / 1$ and $1 / 3$ and CSA $1 / 3$, may be perfectly valid for uses in which a fast-curing product, with high initial strength and a drying shrinkage compensation with a high dimensional stability is required. Based on this, CAC mortars with TFA could be used as repair mortar for structures, roads and industrial pavements requiring high performance, such as: industrial floorings, landing tracks, parking lots, etc. Alternatively, CAC and CSA with TFA mortars could also be used in the manufacture of prefabricated elements without structural reinforcement, given its high bending strength.

\section{ACKNOWLEDGEMENTS}

The authors would like to thank the company Valoriza Servicios Medioambientales, S.A. for the support received through the cooperation agreement established with the Polytechnic University of Madrid, for the research "Proyecto de Investigación y Desarrollo de Sistema de Inertización de Cenizas Volantes de Incineradora" (Código: P115625344). Their gratitude also goes to Emilio Vallejo, quality manager of CEMEX Spain and to Agustín Laplaza from Departamento de Asistencia Técnica y Prescripción de FYM-Italcementi. Likewise, Óscar López Zaldívar would like to thank the collaboration of Santiago Villa, and the staff of the laboratory of Construction Materials of the ETSEM. Thanks also to Isabel Salto-Weiss for the language revision.

\section{REFERENCES}

1. Lam, CHK. (2010) Use of incineration MSW ash: A review. Sustainability 2 [7], 1943-1968. http://dx.doi.org/10.3390/ su2071943.

2. Ferreira, C.; Ribeiro, A.; Ottosen, L. (2003) Possible applications for municipal solid waste fly ash. J Hazard Mater. 96 [2-3], 201-216. http://dx.doi.org/10.1016/S03043894(02)00201-7.

3. Ferreira, C.; Ribeiro, A.; Ottosen, L. (2003) Heavy metals in MSW incineration fly ashes. J Phis IV. Vol. 107. http:// dx.doi.org/10.1051/jp4:20030341.

4. European Commission. Commission Decision on the European List of Waste (COM 2000/532/EC) and Annex III to Directive 2008/98/EC (2008).

5. Iacovidou, E.; Ohandja, D.; Gronow, J.; Voulvoulis, N. (2012) The household use of food waste disposal units as a waste management option: A review. Crit Rev Environ Sci Technol 42 [14], 1485-1508. http://dx.doi.org/10.1080/1064 3389.2011.556897.

6. Mata-Alvarez, J.; Dosta, J.; Macé, S.; Astals, S. (2011) Codigestion of solid wastes: A review of its uses and perspectives including modeling. Crit Rev Biotechnol 31 [2], 99-111. http://dx.doi.org/10.3109/07388551.2010.525496.

7. Battistoni, P.; Cola, E.; Fatone, F.; Bolzonella, D.; Eusebi, A.L. (2007) Micropollutants removal and operating strategies in ultrafiltration membrane systems for municipal wastewater treatment: Preliminary results. Ind Eng Chem Res 46 [21], 6716-6723. http://dx.doi.org/10.1021/ie070017r.

8. Hjelmar, O. (1996) Disposal strategies for municipal solid waste incineration residues. J Hazard Mater 47 [1-3], 345-368. http://dx.doi.org/10.1016/0304-3894(95)00111-5.

9. Sabbas, T.; Polettini, A.; Pomi, R.; Astrup, T.; Hjelmar, O.; Mostbauer, P. (2003) Management of municipal solid waste incineration residues. Waste Manage 23 [1], 61-88. http:// dx.doi.org/10.1016/S0956-053X(02)00161-7.

10. Mangialardi, T. (2003) Disposal of MSWI fly ash through a combined washing-immobilisation process. J Hazard Mater 98 [1-3], 225-240. http://dx.doi.org/10.1016/S03043894(02)00359-X.

11. Mangialardi, T. (2004) Effects of a washing pre-treatment of municipal solid waste incineration fly ash on the hydration behaviour and properties of ash-Portland cement mixtures. Adv Cem Res 16 [2], 45-54. http://dx.doi.org/ 10.1680/adcr.2004.16.2.45.

12. Pan, J.R.; Huang, C.; Kuo, J.; Lin, S. (2008) Recycling MSWI bottom and fly ash as raw materials for Portland cement. Waste Manage 28 [7], 1113-1118. http://dx.doi. org/10.1016/j.wasman.2007.04.009.

13. Andreola, F.; Barbieri, L.; Hreglich, S.; Lancellotti, I.; Morselli, L.; Passarini, F. (2008) Reuse of incinerator bottom and fly ashes to obtain glassy materials. J Hazard Mater 5/30, 153 [3], 1270-1274. http://dx.doi.org/10.1016/j. jhazmat.2007.09.103

14. Haiying, Z.; Youcai, Z.; Jingyu, Q. (2007) Study on use of MSWI fly ash in ceramic tile. J Hazard Mater 3/6, 141 [1], 106-114. http://dx.doi.org/10.1016/j.jhazmat.2006.06.100.

15. Ginés, O.; Chimenos, J.M.; Vizcarro, A.; Formosa, J.; Rosell, J.R. (2009) Combined use of MSWI bottom ash and fly ash as aggregate in concrete formulation: Environmental and mechanical considerations. J Hazard Mater 9/30 169 [1-3], 643-650. http://dx.doi.org/10.1016/j.jhazmat. 2009.03 .141

16. Mangialardi, T.; Panei, L.; Piga, L. (2004) Cement-based immobilisation of municipal incinerator fly ash and reuse 
of solidified products as a construction material. Wit Trans Ecol Envir II, 35.

17. Quina, M.J.; Bordado, J.C.M.; Quinta-Ferreira, R.M. (2014) Stabilisation/solidification of APC residues from MSW incineration with hydraulic binders and chemical additives. J Hazard Mater 1/15 264 [0], 107-116. http:// dx.doi.org/10.1016/j.jhazmat.2013.11.014

18. De Casa, G.; Mangialardi, T.; Piga, L. (2004) Production of artificial aggregates from ceramic processing of municipal incinerator fly ash. Wit Trans Ecol Envir II, 45

19. Mangialardi, T. (2001) Sintering of MSW fly ash for reuse as a concrete aggregate. J Hazard Mater 87 [1-3], 225-239. http://dx.doi.org/10.1016/S0304-3894(01)00286-2.

20. Navarro-Blasco, I.; Duran, A.; Sirera, R.; Fernández, J.M.; Alvarez, J.I. (2013) Solidification/stabilization of toxic metals in calcium aluminate cement matrices. $J$ Hazard Mater 9/15 260 [0], 89-103. http://dx.doi.org/10.1016/j. jhazmat.2013.04.048.

21. Chinchón Yepes, S.; Sanjuán Barbudo, M.A. (2008) El Cemento de Aluminato de Calcio y sus prefabricados. Editorial Universidad de Alicante.

22. Qi Na, S.; Jing Miao, L.; Bao Quan, H.; Ji Bing, W. (2012) Application of Sulfoaluminate Cement for Solidification/ Stabilization of Fly Ash from Municipal Solid Waste Incinerators. Appl Mech Mater 178-181, 795-798. http:// dx.doi.org/10.4028/www.scientific.net/AMM.178-181.795.

23. Puertas, F.; Fernández-Carrasco, L.; Blanco-Varela, M.T.; Vázquez, T.; De La Fuente, A. (1996) Influence of KOH solution on the hydration and carbonation of high alumina cement mortars. J Mater Sci 31 [11], 2819-2827. http:// dx.doi.org/10.1007/BF00355988.

24. Chang, J.C. (1990) Solubility Product Constants. CRC Handbook of Chemistry and Physics. 71st Edition, ed. Boca Raton, FL

25. Aubert, J.E.; Husson, B.; Sarramone, N. (2006) Utilization of municipal solid waste incineration (MSWI) fly ash in blended cement. Part 1: Processing and characterization of MSWI fly ash. J Hazard Mater 136 (3), 624-631. http:// dx.doi.org/10.1016/j.jhazmat.2005.12.041.

26. Aubert, J.E.; Husson, B.; Sarramone, N. (2007) Utilization of municipal solid waste incineration (MSWI) fly ash in blended cement. Part 2. Mechanical strength of mortars and environmental impact. J Hazard Mater 146 [1-2], 12-19. http://dx.doi.org/10.1016/j.jhazmat.2006.11.044

27. European Union. Council Directive 1999/31/EC on the landfill of waste. Official Journal L 182, 1-19. 16 July 1999.

28. European Union. Council Decision 2003/33/EC establishing criteria and procedures for the acceptance of waste at landfills pursuant to article 16 of and Annex II to Directive 1999/31/EC. Official Journal of the European Union L 11, 27-49. 16 January 2003.

29. Cinquepalmi, M.A.; Mangialardi, T.; Panei, L.; Paolini, A.E.; Piga, L. (2008) Reuse of cement-solidified municipal incinerator fly ash in cement mortars: Physico-mechanical and leaching characteristics. J Hazard Mater 151 [2-3], 585-593 http://dx.doi.org/10.1016/j.jhazmat 2007.06.026.

30. Lima, A.T.; Ottosen, L.M.; Ribeiro, A.B. (2012) Assessing fly ash treatment: Remediation and stabilization of heavy metals. J Environ Manage 95 (SUPPL.), S110-S115.

31. Rémond, S.; Pimienta, P.; Bentz, D.P. (2002) Effects of the incorporation of Municipal Solid Waste Incineration fly ash in cement pastes and mortars: I. Experimental study. Cem Concr Res 32 [2], 303-311. http://dx.doi.org/10.1016/ S0008-8846(01)00674-3.

32. Rémond, S.; Bentz, D.P.; Pimienta, P. (2002) Effects of the incorporation of Municipal Solid Waste Incineration fly ash in cement pastes and mortars - II: Modeling. Cem Concr Res 32 [4], 565-576. http://dx.doi.org/10.1016/S00088846(01)00722-0.

33. Lo, Y.; Lee, H.M. (2002) Curing effects on carbonation of concrete using a phenolphthalein indicator and
Fourier-transform infrared spectroscopy. Build Environ 5, 37 [5], 507-514. http://dx.doi.org/10.1016/S0360-1323 (01) $00052-\mathrm{X}$.

34. Chang, C.; Chen, J. (2006) The experimental investigation of concrete carbonation depth. Cem Concr Res 9, 36 [9], 1760-1767. http://dx.doi.org/10.1016/j.cemconres. 2004.07.025.

35. Filippov, L.; Thomas, F.; Filippova, I.; Yvon, J.; MorillonJeanmaire, A. (2009) Stabilization of NaCl-containing cuttings wastes in cement concrete by in situ formed mineral phases. J Hazard Mater 11/15, 171 [1-3], 731-738. http:// dx.doi.org/10.1016/j.jhazmat.2009.06.065.

36. Barbosa, R.; Lapa, N.; Lopes, H.; Gulyurtlu, I.; Mendes, B. (2011) Stabilization/solidification of fly ashes and concrete production from bottom and circulating ashes produced in a power plant working under mono and co-combustion conditions. Waste Manage 0, 31 [9-10], 2009-2019. http:// dx.doi.org/10.1016/j.wasman.2011.04.020.

37. Zornoza, E.; Payá, J; Garcés, P. (2008) Chloride-induced corrosion of steel embedded in mortars containing fly ash and spent cracking catalyst. Corros Sci 6, 50 [6], 1567-1575. http://dx.doi.org/10.1016/j.corsci.2008.02.001.

38. Ministerio de Fomento. Secretaría General Técnica. EHE2008. Instrucción de Hormión Estructural. Serie Normativa. 2010; $4^{\mathrm{a}}$ Edición.

39. Vedalakshmi, R.; Sundara Raj, A.; Srinivasan, S.; Ganesh Babu, K. (2003) Quantification of hydrated cement products of blended cements in low and medium strength concrete using TG and DTA technique. Thermochim Acta 12/5, 407 [1-2], 49-60. http://dx.doi.org/10.1016/S0040-6031(03)00286-7.

40. Rajamma, R.; Ball, R.J.; Tarelho, L.A.C.; Allen, G.C.; Labrincha, J.A.; Ferreira, V.M. (2009) Characterisation and use of biomass fly ash in cement-based materials. $J$ Hazard Mater 12/30,172[2-3],1049-1060. http://dx.doi.org/10.1016/ j.jhazmat.2009.07.109.

41. Sepulcre-Aguilar, A.; Hernández-Olivares, F. (2010) Assessment of phase formation in lime-based mortars with added metakaolin, Portland cement and sepiolite, for grouting of historic masonry. Cem Concr Res 1, 40 [1], 66-76. http://dx.doi.org/10.1016/j.cemconres.2009.08.028.

42. Gazulla, M.F.; Gómez, M.P.; Ordu-a, M.; Silva, G. (2005) Caracterización química, mineralógica y térmica de boratos naturales y sintéticos. Boletín de la Sociedad Española de Cerámica y Vidrio 44 [1], 21-31. http://dx.doi.org/10.3989/ cyv.2005.v44.i1.399.

43. Gunasekaran, S.; Anbalagan, G. (2008) Spectroscopic study of phase transitions in natural calcite mineral. Spectrochimica Acta Part A: Molecular and Biomolecular Spectroscopy 4, 69 [4], 1246-1251. http://dx.doi.org/10.1016/ j.saa.2007.06.036.

44. Taylor, H.F.W. (1997) Cement Chemistry. Thomas Telford Ltd; 2nd Edition. http://dx.doi.org/10.1680/cc.25929.

45. Wang, L.; Jin, Y.; Nie, Y. (2010) Investigation of accelerated and natural carbonation of MSWI fly ash with a high content of Ca. J Hazard Mater 174 [1-3], 334-343. http:// dx.doi.org/10.1016/j.jhazmat.2009.09.055.

46. Kessler, B ; Rollet, M.; Sorrentino, F. (1992) Microstructure of cement pastes as incinerator ash host. Proceedings of the first international Symposium on cement industry solution to waste management. Calgary. Pp: 235-251.

47. Péra, J.; Ambroise, J. (2004) New applications of calcium sulfoaluminate cement. Cem Concr Res 34 [4], 671-676. http://dx.doi.org/10.1016/j.cemconres.2003.10.019.

48. Klemm, W; Siedel, H. (2002) Evaluation of the origin of sulphate compounds in building stone by sulphur isotope ratio. Geol Soc Sp 205, 419-429. http://dx.doi.org/10.1144/ GSL.SP.2002.205.01.30.

49. Auer, S.; Kuzel, H.; Pöllmann, H.; Sorrentino, F. (1995) Investigation on MSW fly ash treatment by reactive calcium aluminates and phases formed. Cem Concr Res 25 [6], 1347-1359. http://dx.doi.org/10.1016/0008-8846(95)00127-X. 